\title{
Antecedents of green supply chain practices in developing economies
}

\begin{abstract}
Purpose - This paper investigates the current state of green supply chain practices and also introduces a framework for the implementation of green supply chain practices in India.

Design/methodology/approach - A case study approach was used for this research in which semi-structured interviews were conducted with three companies. These companies are automobile component manufacturing companies.

Findings - In the three case studies, there were different antecedents depending upon the specific company structure and organization. The ten green supply chain practices were used as a base for finding the antecedents.

Practical implications - The outputs of this research work will pave a path for other automobile component manufacturing companies in India to address and implement green supply chain practices.
\end{abstract}

Keywords- Green supply chain, Emerging economies, Antecedents of green supply chain, Supply chain management

Paper type - Research paper

\section{Introduction}

It has long been observed that firms focus on generic strategies (Porter, 1980) and on their core competencies (Prahalad \& Hamel, 1990). This leads the firms to outsource their non-core activities and production of low value and low-technological parts and subassemblies to lower-cost providers. Manufacturers also compete on cost (Hayes \& Wheelwright, 1984). This outsourcing has led to manufacturers transferring production to low-cost economies.

By outsourcing, production firms reduce costs. However, this creates other challenges. One of these is a greater negative environmental impact due to the need to transport these outsourced goods (Green et al, 1996). Legislative and regulatory compliance requires organisations to become more sustainable and reduce environmental impact. This also paves the path for organisations to adapt the circular business model (Kumar et al, 2019; Laing et al, 2019; Jaeger and Upadhyay, 2020). The circular business model also explores the relationship between sustainability and environmental management in organisations (Chugani et al, 2017; Garza-Reyes et al, 2018; Gomez-Trujillo et al, 2020).

Thus firms are encouraged to implement green supply chain practices (GSCP). It is interesting to explore the antecedents which prevailed in the past and still play a vital role in green supply chain implementation and practice. This paper explores the literature on green supply chain practice and presents models for green supply chain management and green supply chain practice. The models are based on different prevalent philosophies, and tools and techniques for green supply chain management and practices respectively. The paper is divided into three main parts; Introduction, literature review and framework 
(which also includes the discussion). The literature review starts with sustainable supply chain management and builds the theory for developing a framework for green supply chain practice.

There are two objectives for this paper: Describing the current state of green supply chain practice, and understanding the antecedents for green supply chain practice in developing economies.

\section{Literature Review}

\subsection{Sustainable Supply Chain Management}

Sustainable supply chain management (SSCM) is linked with supply chain management and environmental management. SSCM integrates environment thinking into supplychain management, including product design, material sourcing and selection, manufacturing processes, delivery of the final product to the consumers as well as endof-life management of the product after its useful life (Srivastava, 2007). Hence it involves sustainability in the entire supply chain starting from raw material sourcing to the final consumption. Environmental awareness and the government regulations are also big factors in prompting organizations to take necessary steps towards sustainability and supply chain is a key consideration in moving in the right direction.

The interaction between sustainability and supply chains is the critical next step from recent examinations of operations and the environment (Corbett and Kleindorfer, 2003) and operations and sustainability (Kleindorfer et al., 2005). A focus on supply chains is a step towards the broader adoption and development of sustainable supply chain, since the supply chain considers the product from initial processing of raw materials to delivery to the customer (Linton et al, 2007). Supply chain is crucial from the first stage (raw material processing) to the delivery to the end-customer and beyond this to recollection, recycling and remanufacturing of the product. However, sustainable supply chain should also focus on issues which are beyond the normal supply chain management: product design, manufacturing by-products, by-products produced during product use, product life extension, product end-of-life, and recovery processes at end-of-life. Lee and Rhee (2007) developed four types of environmental strategies: reactive, focused, opportunistic, and proactive. Reactive strategies are applied for low levels of environmental responsiveness; focused strategies for high levels of environmental management; opportunistic strategies for a medium level; and proactive strategies to the latest environmental practices. Research showed that organizations could achieve their business goals and also reduce environmental impact (Melnyk et al, 2003). However, there is no guarantee that all the investment in sustainable practices will bring cost savings and ultimately generate profit. This becomes a major issue when the investment in sustainable supply chain practice is proactive, and then it may not pay off for decades (Wu and Pagell, 2011). However, there are some organizations, which take bold sustainable supply chain action at the expense of the financial health of the organization. This is a risky proposition, sometimes it pays off in the future and sometimes it does not. The author argues that it depends upon the mission and vision of the organization; what does an organization want to achieve in the long run? Moreover, sometimes organizations change their decisions mid-way depending upon various internal and 
external factors and these organizations operate in a dynamic and complex setting (Devinney, 2009).

There is a wide range of literature available on different aspects and issues of sustainable supply chain management. These include green design (Zhang et al. 1997), green manufacturing and product recovery (Guide et al. 1996; Gungor and Gupta 1999), reverse logistics (Carter and Ellram 1998; Fleischmann et al. 1997), production planning and control for remanufacturing (Bras and Mclntosh 1999; Guide 2000) and logistics networks redesign (Jayaraman et al. 2003). These aspects and issues come together and form sustainable supply chain practices, which can be used in alignment with other practices. The next step is to explore the sustainable supply chain practices.

\subsection{Sustainable supply chain practices}

To reduce environmental impact there are sustainable supply chain practices which affect the organization in the short-term and also in long-term. It has been suggested that life cycle assessment is used to design a product to minimize the environmental impact over its life and afterwards (Pennington et al, 2004). This is a step towards sustainable supply chain practices.

Sustainable supply chains require awareness about sustainable practices like ethical sourcing (Roberts, 2003), green purchasing (Rao and Holt, 2005), environmental purchasing (Min and Galle, 1997), and logistics social responsibility (Carter and Jennings, 2002). Different sustainable practices cover the specific area in supply chain. Moreover, it also defines the boundaries for every unique practice and its effect on the whole supply chain. I argue here that it's not possible and appropriate to implement all the sustainable supply chain practices in an organization. These practices are sometimes specific to the different domain areas. At the supply chain level, organizations that involve suppliers and third parties in the sustainable process early and well in advance of competitors start a development path that may provide a sustained competitive advantage that lasts well into the future. Hence it is very important for organizations to involve the vendors, suppliers and third parties in their sustainability process. There is immense pressure on manufacturing organizations to go greener and reduce the impact on the environment. A taxonomy of green supply chain management (GSCM) practices has also developed to understand the complex relationship between internal and external green supply chain factors (Kumar et al, 2015; Chowdhury et al, 2016; Mangla et al, 2018; Upadhyay et al, 2019; Tseng et al, 2019). Attitudes and levels of environmental risk and impact are key mediators between internal drivers, external drivers and green supply chain management operational practices.

Organizations are continuously monitoring their practices by implementing environmental collaboration with customers and suppliers and also by using environmental technologies (Vachon, 2007). These include certification of their suppliers and evaluating the new suppliers on the basis of their contribution towards the organization's sustainability goal. Remanufacturing and recycling of used products is also a major concern for organizations. Green supply chain management and green supply chain practices are the next to be discussed for the development of the framework. 


\subsection{Green Supply Chain Management}

Green Supply Chain Management (GSCM) is a broad term which covers activities such as green design, green sourcing/procurement, green operations or green manufacturing', 'green distribution, logistics'/marketing' and 'reverse logistics' (Srivastava, 2007). However, the green supply chain management concept also covers all phases of a product's life cycle, from the extraction of raw materials through the design, production, and distribution phases, to the use of the product by consumers and its disposal at the end of the product's life cycle (Walker et al., 2008; Hervani et al., 2005). Zhu and Sarkis (2004) discussed the broad perspective of Green supply chain management and include internal and external practices that play a vital role in greening the supply chain. They developed four factors for Green supply chain practices:

- Internal environmental management

- External green supply chain management

- Investment recovery

- Eco-design

These four factors constitute the four main categories for green supply chain management. Now we move to green supply chain practices to explore their nature and classify into different categories.

\subsection{Green Supply Chain Practices}

Several papers discuss environmental issues in the supply chain (Bowen et al. 2001, Zhu and Sarkis 2004). However, a clear and widely accepted definition of green supply chain practices is lacking (Klassen and Johnson 2004).

In 2006, the internalization/externalization framework from international management literature (Buckley and Casson 1976) was proposed as a theoretical foundation to categorize environmental management in the supply chain (Vachon and Klassen 2006). The framework, which was also used to characterize supplier development activities (Krause et al. 2000) and corporate social responsibility (Husted 2003), suggests that organizations can either conduct activities through markets (externalizing) or by incorporating those activities within the organization hierarchy (internalizing). Using a similar premise, Vachon and Klassen (2006) put forward the concept of green supply chain practices, which comprise two sets of related yet independent environmental activities: Environmental collaboration and environmental monitoring. Hence, an organization's green supply chain practices imply

(i) Internalizing by integrating its environmental management activities with other organizations in the supply chain or

(ii) Externalizing environmental management in the supply chain by employing market-based mechanisms. The former is termed environmental collaboration while the latter is environmental monitoring (Vachon and Klassen 2006).

The most comprehensive set of green supply chain practices comprises environmental collaboration (internalizing by integrating its environmental management activities with other organizations in the supply chain) and environmental monitoring (externalizing environmental management in the supply chain by employing market-based 
mechanisms) as suggested by Vachon and Klassen (2006). However, it's still not clear which activities an organization should internalize or externalize with other organizations in supply chain.

For supply chain management, boundary-spanning environmental practices remain particularly challenging, as two or more organizations actively work to coordinate and integrate their management and technological systems. Key green supply chain practices (Klassen and Johnson, 2004) are shown below.

- Environmental certification

- Pollution prevention

- Life cycle assessment (LCA)

- Design for the environment

- Reverse logistics

Here the important thing is that two or more organizations come together to work on environmental issues and coordinate and integrate their systems. There are different views on classifying the green supply chain practices and Zhu and Sarkis (2005) classified the green supply chain practices in five different ways shown below.

- Internal environmental management

- Green Purchasing

- Cooperation with customers including environment requirement

- Investment recovery

- Eco-design practices

The green supply chain practices as mentioned above constitute a cluster of green supply chain practices. These practices are used differently in different sectors. In some sectors, it is easier for organizations to implement these green supply chain practices than in other sectors.

\section{Framework and Discussion}

A theoretical framework has been developed for the green supply chain practices on the basis of the different prevalent philosophies and tools and techniques as shown in table 1. It also includes antecedents, enablers, inhibitors and consequences.

Table 1-Green supply chain practices

\begin{tabular}{|l|l|l|l|l|}
\hline $\begin{array}{l}\text { Green Supply chain } \\
\text { Practices (GSCP) }\end{array}$ & Antecedents & Enablers & Inhibitors & Consequences \\
\hline $\begin{array}{l}\text { (Klassen and } \\
\text { Johnson, 2004; } \\
\text { Mangla et al, 2013; } \\
\text { Cousins et al, 2019) }\end{array}$ & & & & \\
\hline $\begin{array}{l}\text { Environmental } \\
\text { certification }\end{array}$ & $\begin{array}{l}\text { Addressing } \\
\text { environmental } \\
\text { consideration }\end{array}$ & $\begin{array}{l}\text { Application of } \\
\text { continuous } \\
\text { improvement } \\
\text { models }\end{array}$ & $\begin{array}{l}\text { Different } \\
\text { certifications }\end{array}$ & $\begin{array}{l}\text { Emergence of } \\
\text { environmental } \\
\text { and social } \\
\text { performance }\end{array}$ \\
\hline
\end{tabular}




\begin{tabular}{|c|c|c|c|c|}
\hline $\begin{array}{l}\text { Pollution } \\
\text { prevention }\end{array}$ & $\begin{array}{l}\text { Strong supply } \\
\text { chain } \\
\text { integration }\end{array}$ & $\begin{array}{l}\text { To 'build in' better } \\
\text { environmental } \\
\text { performance }\end{array}$ & $\begin{array}{l}\text { Requires } \\
\text { concerted } \\
\text { efforts }\end{array}$ & $\begin{array}{l}\text { Capturing and } \\
\text { treatment of } \\
\text { pollutants }\end{array}$ \\
\hline $\begin{array}{l}\text { Life cycle } \\
\text { assessment (LCA) }\end{array}$ & $\begin{array}{l}\text { To identify the } \\
\text { environmental } \\
\text { impacts before } \\
\text { hand. }\end{array}$ & $\begin{array}{l}\text { Focus on identifying } \\
\text { environmentally } \\
\text { preferable product } \\
\text { or process } \\
\text { alternatives. }\end{array}$ & $\begin{array}{l}\text { Quantifying } \\
\text { environmental } \\
\text { burden and } \\
\text { impact }\end{array}$ & $\begin{array}{l}\text { Detailed } \\
\text { assessment of } \\
\text { environmental } \\
\text { burden }\end{array}$ \\
\hline $\begin{array}{l}\text { Design for } \\
\text { environment }\end{array}$ & $\begin{array}{l}\text { Early } \\
\text { involvement of } \\
\text { supply function }\end{array}$ & $\begin{array}{l}\text { To identify less } \\
\text { costly and more } \\
\text { effective } \\
\text { opportunity }\end{array}$ & $\begin{array}{l}\text { Unfamiliar to } \\
\text { product } \\
\text { designers }\end{array}$ & $\begin{array}{l}\text { Less waste, and } \\
\text { greater } \\
\text { productivity }\end{array}$ \\
\hline Reverse logistics & $\begin{array}{l}\text { Internalizing } \\
\text { environmental } \\
\text { costs and risk }\end{array}$ & $\begin{array}{l}\text { Quality control, } \\
\text { planning and } \\
\text { scheduling }\end{array}$ & $\begin{array}{l}\text { Management } \\
\text { of inter-firm } \\
\text { relationship }\end{array}$ & $\begin{array}{l}\text { Combination of } \\
\text { re-use, repair, } \\
\text { remanufacturing } \\
\text { or recycling }\end{array}$ \\
\hline \multicolumn{5}{|l|}{$\begin{array}{l}\text { (Zhu and Sarkis, } \\
\text { 2005; Mangla et al, } \\
\text { 2018; Tseng et al, } \\
\text { 2019) }\end{array}$} \\
\hline $\begin{array}{l}\text { Internal } \\
\text { environment } \\
\text { management }\end{array}$ & $\begin{array}{l}\text { Environmental } \\
\text { certification } \\
\text { precedence. }\end{array}$ & $\begin{array}{l}\text { Internal } \\
\text { improvement of } \\
\text { product and } \\
\text { processes. }\end{array}$ & $\begin{array}{l}\text { Internal } \\
\text { resistance to } \\
\text { change and } \\
\text { fear for new } \\
\text { system. }\end{array}$ & $\begin{array}{l}\text { Overall internal } \\
\text { and external } \\
\text { improvement of } \\
\text { environment } \\
\text { management. }\end{array}$ \\
\hline Green purchasing & $\begin{array}{l}\text { Inclusion of } \\
\text { green } \\
\text { performance }\end{array}$ & $\begin{array}{l}\text { Developing green } \\
\text { standards and } \\
\text { specifications. }\end{array}$ & $\begin{array}{l}\text { Identifying, } \\
\text { categorizing } \\
\text { the } \\
\text { purchasing } \\
\text { process. }\end{array}$ & $\begin{array}{l}\text { Focus on } \\
\text { selection and } \\
\text { acquisition of } \\
\text { product and } \\
\text { services }\end{array}$ \\
\hline $\begin{array}{l}\text { Cooperation with } \\
\text { customers including } \\
\text { environmental } \\
\text { requirements }\end{array}$ & $\begin{array}{l}\text { Downstream } \\
\text { cooperation for } \\
\text { environmental } \\
\text { management } \\
\text { impact. }\end{array}$ & $\begin{array}{l}\text { Customer's } \\
\text { awareness and } \\
\text { involvement in such } \\
\text { initiatives. }\end{array}$ & $\begin{array}{l}\text { Information } \\
\text { sharing and } \\
\text { integration in } \\
\text { downstream. }\end{array}$ & $\begin{array}{l}\text { Production of } \\
\text { environmental } \\
\text { friendly } \\
\text { products and } \\
\text { services. }\end{array}$ \\
\hline $\begin{array}{l}\text { Investment } \\
\text { recovery }\end{array}$ & $\begin{array}{l}\text { Recouping the } \\
\text { value of assets }\end{array}$ & $\begin{array}{l}\text { The resale of assets } \\
\text { via online } \\
\text { disposition avenues } \\
\text { such as online } \\
\text { auctions. }\end{array}$ & $\begin{array}{l}\text { Clear } \\
\text { understanding } \\
\text { of } \\
\text { environmental } \\
\text { principles and } \\
\text { policies. }\end{array}$ & $\begin{array}{l}\text { Increase in } \\
\text { corporation's } \\
\text { return on } \\
\text { surplus assets }\end{array}$ \\
\hline
\end{tabular}

To develop the framework, an in-depth theoretical analysis of different prevalent 
philosophies of green supply chain practices was done in conjugation with different tools and techniques. Green supply chain practices were selected on the basis of theoretical evidence (Klassen and Johnson, 2004; Zhu and Sarkis, 2005; Mangla et al, 2013; Mangla et al, 2018; Tseng et al, 2019; Cousins et al, 2019) and were considered as the benchmark for this research. Enablers and inhibitors give the extra strength to the framework because they explore the green supply chain practices in a wider context and include all the possibilities.

This framework is useful in implementation of green supply chain practices and also gives detail about the different philosophies behind the framework. The data has been collected through semi-structured interviews in the four public listed manufacturing companies. Analysis of the data gives a clear picture and the feasibility of the above framework. It will be interesting to see the consequences in the framework after the data analysis and this can give further direction for research in the area of green supply chain practices. Another interesting area for future research will be to analyse green supply chain practices in family-owned companies.

\section{Research Methodology}

The methodology chosen to answer the research questions mentioned above is an inductive, multiple-case study. Eisenhardt (1989) says that a case study is a methodology that focuses on understanding the dynamics present within single settings. A case study is a research strategy to build theories; using empirical evidence on cases - i.e., instances of a class of events under scrutiny (George and Bennett, 2005) - creates theoretical constructs, propositions and/or midrange theory (Eisenhardt and Graebner, 2007).

The case research method allows the questions of why, what and how, to be answered with a relatively full understanding of the nature and complexity of the complete phenomenon (Voss et al., 2002; Bebensat et al., 1987; Meredith, 1998; Yin, 2003). Hence it seems, therefore, a perfect fit for a study interested in understanding interorganization dynamics from green supply chain practice perspectives.

For this research, the qualitative research process using multiple case studies was chosen. There are various reasons for this as follows:

$>$ Green supply chain practices are a vast collection of techniques. Hence, selection of green supply chain practices and strategies can be a complex process. In such a dynamic setting it is best to use qualitative research methodology (using case studies) to understand the situation.

> Face-to-face meetings with respondents can help provide understanding and information on several qualitative areas, such as reasons for implementing specific green supply chain practice, process, discussions and feedback.

$>$ A multiple-case study can provide a robust insight and thus achieve a higher level of external validity and reliability. Cases can be viewed and studied alone and across cases (within-case analysis and cross-case analysis) to provide comparison and contrast and richer details and insights regarding the research issues (Eisenhardt, 1989; Yin, 2003).

It has been noted that, the convenience and confidentiality of telephonic interviews lack non-verbal communication (Beardwell et al, 2003). This limitation is significant as non- 
verbal communication plays an important role during in-depth interview studies in a sense that the researcher can observe the physical reaction of an interviewee to a question by reading body language (Marshall \& Rossman, 1999). However, due to resource constraints, it was necessary to conduct telephone interviews on this occasion.

\subsection{Design of Case Studies}

Multiple case study design is the most favoured approach for this research. Van Aken (2004) states that through multiple case studies one can accumulate supporting evidence, which can continue until 'theoretical saturation' (Eisenhardt, 1989) has been obtained.

The multiple case studies are regarded as very robust (Herriott and Firestone, 1983) because the evidence from multiple case studies is more compelling. The studies for this work have been designed on three-phase approaches as shown in table 2.

Table 2: Three-phase approach for research

\begin{tabular}{|c|c|c|c|c|}
\hline No & Phase & $\begin{array}{l}\text { No of } \\
\text { Cases }\end{array}$ & Objective & Time Elapsed \\
\hline 1 & Pilot case & 1 & $\begin{array}{l}\text { - Explain the current state of green } \\
\text { supply chain practices } \\
\text { - Describe and understand the } \\
\text { antecedents of green supply } \\
\text { chain practices. } \\
\text { - Refine the case study design }\end{array}$ & $\begin{array}{l}\text { 3-4 months / } \\
\text { case }\end{array}$ \\
\hline 2 & Core cases & 2 & $\begin{array}{l}\text { - Explain the current state of green } \\
\text { supply chain practices } \\
\text { - Describe and understand the } \\
\text { antecedents of green supply chain } \\
\text { practices. }\end{array}$ & $\begin{array}{l}\text { 3-4 months / } \\
\text { case }\end{array}$ \\
\hline 3 & $\begin{array}{l}\text { Cross-case } \\
\text { comparison }\end{array}$ & $\begin{array}{l}3 \text { (Pilot } \\
\text { and } \\
\text { core) }\end{array}$ & $\begin{array}{l}\text { - Compare the underlying states } \\
\text { across the } 3 \text { different green supply } \\
\text { chain contexts to develop a } \\
\text { strategic framework and set of } \\
\text { concepts and guidelines. }\end{array}$ & $\begin{array}{l}\text { Continuous } \\
\text { process }+1-2 \\
\text { months at } \\
\text { the end }\end{array}$ \\
\hline & Total & 3 & & \\
\hline
\end{tabular}

There are three cases, which form the heart of the study across all three phases. These cases describe the current state of green supply chain practices, antecedents and enablers. The first case should be considered as a pilot, as it will also be used to refine and develop the research design (Ellram, 1996). The third stage was cross-case analysis, 
which compares the three cases to develop a strategic framework and to develop guidelines.

There are a number of different processes for conducting case study research. Flynn (1990) developed a six-stage systematic approach for empirical research. Flynn's Model is not restricted for case study research hence it includes an extra step to enable the selection of research design. Yin (1994) and Stuart et al. (2002) suggested a five-phase process as shown in figure 1

Figure 1: Empirical research process
Theoretical foundation
Data collection method
Data analysis $\Longrightarrow$ Publication principles:
1.) Application of multiple sources of evidence
2.) Database of the case study record
3.) Keep the record of evidence

$\Rightarrow$ Implementation

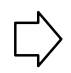

The data collection process is explained by Yin (1994) by the help of three independent

\subsection{Application of Multiple Sources of Evidence}

The data collection was in the form of fieldwork for this research. As discussed earlier, the primary research instrument for data collection was semi-structured interviews, which were developed in line with the interview protocol. A protocol was developed in which the interviews were conducted. Firstly, a quiet place was selected for interviews usually a meeting room or seminar room and booked for the duration of the interview and interviewees were told that the interviews would be recorded. Notes were also taken during the interviews. These notes were then turned into 'contact notes' within twenty-four hours of conducting the interviews as recommended by Miles \& Huberman (1994)

\subsection{Database of Case Study Record}

The difficult job was to keep a track record of a large amount of data collected through primary and secondary sources. A database of case study records was created. Contact notes were already in electronic form and secondary data was also requested in electronic format. In a case where the electronic format was not available, the documents were scanned and stored in electronic format. All documents were then stored in a project-specific folder to enable easy navigation. A summary of case documents was produced in word format and held in the project folder. The main aim was to keep the record of all the evidence collected during fieldwork.

\subsection{Data Analysis}


The data analysis approach for this research work was aligned with the reporting protocol. The implicit analysis was there at various stages, however, for verification and dissemination there were two key types of analysis

1) Individual analysis

2) Cross case analysis

\subsection{Individual Analysis}

For the pilot and core cases, the analysis was the same. After the completion of the scoping study, a report was developed which provided a summary of the outer and inner context, the research focus for the main study and insight on any company-specific questions. The research is in the form of descriptive analysis is based on the information gained from direct questioning as part of the scoping study; and is targeted to both academic and practitioner audiences. The research and analysis were based on the review of contact notes and secondary information documents. The data was extracted from the contact notes by name and reference number and then used for technical analysis.

\subsection{Cross-Case Analysis}

The individual case analysis was helpful in finding the company-specific insights while cross-case analysis helped in developing a generative mechanism or guiding principles to understand the antecedents in the implementation of green supply chain practices. The cross-case analysis was largely iterative and it was based on the individual case analysis, which mirrored the structure, and format of the individual case report. This then provided the platform for the second level of explanatory analysis, which identified what was emerging across the cases.

\subsection{Rigour of Research Design}

The rigour of the research is achieved by the five-stage process (Stuart et al., 2002; Yin, 2003), which was used to structure the methodology in the earlier section.

The COSMOS Corporation, cited in Yin, has developed a series of case study tactics to check the quality of case study research as shown in table 3. Multiple case studies were used for external validity and to develop generative mechanism to explore the antecedents in the implementation of green supply chain practices. Internal validity is increased through pattern matching and explanation building, however, it was not appropriate to use time analysis. At the data collection stage, the author used both techniques following case study protocols and maintaining database established reliability.

Table 3: Ensuring the quality of the research

\begin{tabular}{|c|c|c|c|}
\hline Parameters & Case study tactics & $\begin{array}{c}\text { Used for this } \\
\text { research }\end{array}$ & $\begin{array}{c}\text { Stage of research where } \\
\text { tactic used }\end{array}$ \\
\hline
\end{tabular}




\begin{tabular}{|c|c|c|c|}
\hline $\begin{array}{c}\text { Construct } \\
\text { Validity }\end{array}$ & $\begin{array}{c}\text { Use of multiple sources for } \\
\text { data collection } \\
\text { Establishing a link of evidence }\end{array}$ & Yes & Data collection stage \\
\hline $\begin{array}{c}\text { Internal } \\
\text { Validity }\end{array}$ & $\begin{array}{c}\text { Explanation building } \\
\text { Pattern matching } \\
\text { Time series analysis }\end{array}$ & $\begin{array}{c}\text { Yes } \\
\text { Nes }\end{array}$ & Data analysis \\
\hline External & Use of multiple case study for \\
Validity & generalization & Yes & Research design \\
\hline Reliability & Use case study protocol & Yes & Data collection \\
& Develop case study database & Yes & \\
\hline
\end{tabular}

\section{Discussion}

This is focused on providing the response to descriptive 'What' research questions. What are the antecedents of green supply chain practices? The responses to these questions are summarized in the following section.

\subsection{Company ' $A$ '}

At the heart of supply chain practices in Company ' $A$ ' were green supply chain issues. Put in the words of Operations Manager:

'The company islooking forgreensupplychain practices butitsscope isveryvague. It is about thinking of the environment with the operations processes.'

The operations and marketing manager both have different views on green supply chain practices. The marketing manager is more concerned about the better positioning in the market with a green supply chain tag. To quote the marketing manager:

'Definitely, following any of the green supply chain practices play a key role in better marketing of the products.'

Green supply chain practices take the centre stage in projecting the image of the company and boosting the market share and overall image. The President of Strategy considers implementing the green supply chain practices as an incremental process and it should be implemented step by step:

'Themain concern is to select the green supply chain practice step by step, taking one at a time and to see the fit with the existing supply chain practices'.

Pollution prevention and environmental certification are the first steps in moving towards green supply chain practices. It enables organizations to take a proactive 
approach to green supply chain practices. The executive director is determined to take the company to the next stage where it can compete at an international level by adopting and following the green supply chain practices. The view of the Executive Director was:

'Green supply chain practices are now a necessity to compete in the globalized market and to get the edge over the competitors.'

The need is to involve the customers and suppliers as joint partners in green supply chain initiatives. The collaboration goes with both suppliers and customers. The design for environment and life cycle assessment are most important and directly affect the product and the customer. Customers' involvement in these green supply chain practices can really change the future of green supply chain practices. The Purchasing Executive expressed an appreciation of green purchasing practices:

'Green purchasing is the order of the day, if we follow green purchasing practices and implement it in our system then it will be cost-effective in future and ultimately will give us an edge over the competitors.'

\subsection{Company ' $B$ '}

The Manager of Development was concerned about the involvement of supply function in the product design process, here in his words:

'At the design stage, we should be more focused on suppliers also. For example, we should consider who could be the prospective supplier on the basis of their green supply chain practices'

The General Manager also agreed with the fact that most of the suppliers are not following green supply chain practices, which can affect the overall green supply chain commitment of the company. In the words of the General Manager:

'Involving the suppliers at the design stage and keep them informed about the company's commitment towards green supply chain practices is useful.'

Another important aspect is the involvement of customers at the product development stage. Product development is the crucial stage, which decides the fate of the products. Developing products which are environmentally friendly and which don't affect the environment adversely is important. The director of operations was responsible for streamlining the various operations according to the requirements of new products.

The various stakeholders in the company are also getting concerned about the sustainable practices of the company. These stakeholders include local government, the local council, residential associations and Non-Government Organizations (NGOs) who 
are concerned about the workings of the company and the practices followed by the company. As echoed by the Director of Strategy:

'The local government, council, NGO's and residential associations play a big role in influencing attitudes to, and the image of the company. Company ' $\mathrm{B}$ ' has a long term relationship with the local stakeholders and keeps them informed about all the new sustainable practice initiatives started by the company.'

Purchasing is a very crucial function of any organization. It becomes even more important in auto component manufacturing companies who purchase various parts in the form of sub-assemblies. The Vice President of Projects said:

'We try to add a very specific clause in our purchase orders to the sub-assembly suppliers which clearly states our green supply chain practices and also give them an understanding of what we expect from them.'

\subsection{Company ' $C$ '}

It was interesting to see that the relevant Heads of different products were aware of the issues faced by their areas. The Chief Technology officer showed his focus on green supply chain issues:

'Green Supply chain practices are taking the centre stage in the company and every department and division in the company is working towards it.'

The starting point for green supply chain practices is certification and pollution control. In company ' $C$ ' the focus is more of green design and how to involve the customers in the design stage and enable them to contribute. The Manager of Development suggested:

'Company ' $C$ ' is concerned about enhancing the green design skill of engineers by providing them proper training and monitoring their progress.'

Training plays a vital role in enhancing the skills of design engineers, which ultimately improves the green design practices. Young engineers are passionate about learning new design practices especially with a sustainable approach, so sometimes the design engineer brings green design training issues. Company $\mathrm{C}$ is a mechanical engineeringfocused company and most of the work involves knowledge of mechanical engineering applications and techniques.

The Design Manager echoed similar views stating that:

'...Training with specific green design technology issues improves the Life Cycle Assessment (LCA) which helps in analyzing the effect on the environment.' 
Involving the local authorities is helpful in understanding the regional requirements and their expectations. Involving the local stakeholders is crucial during the starting of a new plant or launching a new production line. The Chief Information Officer discussed his view that involving local authorities during launching a new production line, is helpful in understanding local pollution control and other relevant laws.

\subsection{Cross Case Analysis}

The strength of multiple case study research is that it provides theoretical or literal replication (Yin, 1994) of results. This is often contemplated as more compelling, and the overall study is regarded as more robust (Herriott and Firestone, 1983). However green supply chain practices are very content-specific in nature and literal replication is questionable hence research design sought to provide an opportunity to look for theoretical replication of the guiding principles and generative mechanisms that underpin the antecedents of green supply chain practices. This section presents the comparative case data that provides a response to research questions.

The green supply chain practices followed by these three companies are different from each other and all three companies are at a different stage of implementing green supply chain practices. Table 4 illustrates the current stage of these companies. Company $A$ is the most advanced company in terms of adopting new technology, standards and regulations. They have adopted and implemented various quality, environmental and design standards to help them in successfully implementing the green supply chain practices. Company B and Company Care working towards implementing green supply chain practices but are not as advanced.

Table 4: Green supply chain practices status in cases

\begin{tabular}{|c|c|c|c|c|}
\hline S. No & $\begin{array}{l}\text { Green Supply Chain } \\
\text { Practices \Cases }\end{array}$ & Company A & Company B & Company $\mathrm{C}$ \\
\hline 1 & $\begin{array}{l}\text { Environmental } \\
\text { certification }\end{array}$ & $x$ & $x$ & $x$ \\
\hline 2 & Pollution prevention & $x$ & $x$ & $x$ \\
\hline 3 & $\begin{array}{l}\text { Life cycle assessment } \\
\text { (LCA) }\end{array}$ & & $x$ & \\
\hline 4 & $\begin{array}{l}\text { Design for the } \\
\text { environment }\end{array}$ & & $x$ & \\
\hline 5 & Reverse logistics & & $x$ & \\
\hline 6 & $\begin{array}{l}\text { Internal environmental } \\
\text { management }\end{array}$ & $x$ & & \\
\hline
\end{tabular}




\begin{tabular}{|l|l|l|l|l|}
\hline 7 & Green Purchasing & X & & \\
\hline 8 & $\begin{array}{l}\text { Cooperation with including } \\
\text { customer } \\
\text { environment } \\
\text { requirement }\end{array}$ & $X$ & $X$ \\
\hline 9 & Investment recovery & & & \\
\hline 10 & Eco-design practices & & $X$ & \\
\hline
\end{tabular}

The antecedents for all three companies are quite similar to each other because they work in the same sector and are of a similar size: The business and environment conditions faced by them are quite similar.

In the three case studies, there were different antecedents depending upon the specific company structure and organization. The ten green supply chain practices act as a base for finding the antecedents. The Micro model for green supply chain practices focuses on various green supply chain practices as suggested by Klassen and Johnson (2004) and Zhu and Sarkis (2005). For each green supply chain practice, antecedents are studied and explored. Life Cycle Assessment (LCA) is antecedent for environmental certification and LCA is used to identify the environmental impacts before the product is actually launched. Reverse logistics leads to combining reuse, repair, remanufacturing, and recycling activities. Environmental certification is a precedent for internal environmental management. Focus on green purchasing leads to selection and acquisition of products and services, which minimize the negative effect on the environment over their cycle.

\section{Conclusion}

To address the current state of green supply chain practices, a thorough literature review was completed around sustainability and then narrowed down with the consideration of green supply chain practices. The literature study started with the history of sustainability and green supply chain practices. Several papers discuss environmental issues in the supply chain (Bowen et al., 2001; Zhu and Sarkis, 2004; Bhattacharya et al, 2014). However, a clear and widely accepted definition of green supply chain practices is lacking (Klassen and Johnson, 2004; Mangla et al, 2018; Cousins et al, 2019; Tseng et al, 2019). There is no such specific definition for green supply chain practices hence different authors give the common characteristics of green supply chain practices. A macro model was developed with different philosophies on green supply chain practices as shown in table 1.

Another objective was to explore the antecedents of green supply chain practices. The antecedents were discussed in the theory for the different green supply chain practices. Hence first the green supply chain practices were studied and then ten green supply chain practices were selected (Klassen and Johnson, 2004; Zhu and Sarkis (2005; Cousins et al, 2019; Kumar et al, 2019).

A micro-economic model was developed to show the antecedents of green supply chain 
practices. This model consists of ten green supply chain practices and the antecedents associated with them.

In the three case studies, there were different antecedents depending upon the specific company structure and organization. The ten green supply chain practices act as a base for finding the antecedents. For each green supply chain practice, antecedents are studied and explored. For example, Life Cycle Assessment (LCA) is antecedent for environmental certification and LCA is used to identify the environmental impacts before the product is actually launched.

\subsection{Contribution to theory}

These research studies have contributed both to the development and testing of theory relating to the antecedents of green supply chain practices. The review of literature has provided a synthesis of the underpinning bodies of literature that has not previously been conducted in this way. This resulted in the identification of ten core green supply chain practices for the development of antecedents and has created thefoundation for this empirical investigation. It was found that previous studies have been largely theoretical. The empirical studies that do exist have focused on one particular dyadic relationship within green supply chain practices. A double contribution has been made to testing the theory of green supply chain practices from a process and output perspective. From a process perspective, a contribution has been made to methodology by developing a robust approach for conducting supply chain research beyond the dyad. From an output perspective, the author has the empirical results from the three individual case studies and their cross-case comparison for dissemination to an academic audience.

\subsection{Limitations and future direction for research}

Although every step has been taken to ensure the rigour and reliability of case studies, in a field as complex as green supply chain practice there are inevitably some limitations. Due to the limited size of the case study approach, the results can only be generalized to a similar size and types of organization. The scope of data collection for all three case studies was the same, but the quality of information gathered varied. As demonstrated earlier, good quality cross-case analysis was still possible but the relative strengths of the three cases varied. This research employs the case study methodology that relies primarily on an inductive approach to obtain data for analytical generalization rather than statistical generalization. Thus, the focus of this research is theory building and analytical generalization. It is recommended that further research should test this theory using a larger sample and using a more quantitative research method for the purpose of statistical generalization. After all, qualitative and quantitative methods are complementary to each other and enhance investigation findings. In this research, only automobile component manufacturing companies in India have been studied. Future research can extend to different geographical areas providing another opportunity for insight through comparison. Future research can also try to understand if there is different behaviour towards green supply chain practices of different companies, such as traditional and progressive manufacturing companies. 


\section{References}

Beardwell, I. Holden, L. and Claydon, T. (2003), Human Resource Management: A Contemporary Approach, London: Pearson.

Benbasat, I., Goldstein, D. K., and Mead, M. (1987), "The case research strategy in studies of information systems", MIS Quarterly, vol. 11, no. 3, pp. 369-386.

Bhattacharya, A., Mohapatra, P., Kumar, V., Dey, P. K., Brady, M., Tiwari, M. K., \& Nudurupati, S. S. (2014). Green supply chain performance measurement using a fuzzy ANP-based balanced scorecard: a collaborative decision-making approach. Production Planning \& Control, 25(8), 698-714.

Bowen, F.E., Cousins, P.D., Lamming, R.C. and Faruk, A.C. (2001), The role of supply management capabilities in green supply, Production and Operations Management, 10, 174-189.

Bras, B. and McIntosh, M.W. (1999), Product, process, and organizational design for remanufacture - an overview of research, Robotics and Computer-Integrated Manufacturing, 15, 167- 178.

Buckley, P.J. and Casson, M. (1976), The Future of Multinational Enterprise, MacMillan Press: London.

Carter, C.R. and Ellram, L.M. (1998), Reverse logistics: a review of the literature and framework for future investigation, Journal of Business Logistics, 19, 85-102.

Carter, C.R., Jennings, M.M. (2002), Logistics social responsibility: an integrative 
framework, Journal of Business Logistics, Vol. 23 No.1, pp.145-80.

Chowdhury, M., Upadhyay, A., Briggs, A. and Belal, M. (2016), 'An empirical analysis of green supply chain management practices in Bangladesh Construction Industry', paper presented at the European Operations Management Association Conference (EurOMA), 17-22 ${ }^{\text {nd }}$ June, Trondheim, Norway.

Chugani, N., Kumar, V., Garza-Reyes, J.A., Rocha-Lona, L. and Upadhyay, A. (2017), "Investigating the green impact of Lean, Six Sigma and Lean Six Sigma: A systematic literature review", International Journal of Lean Six Sigma, Vol. 8 No. 1, pp. 7-32.

Corbett, C.J., Kleindorfer, P.R. (2003), Environmental management and operations management: introduction to the third special issue, Production and Operations Management 12 (3), 287-289.

Cousins, P. D., Lawson, B., Petersen, K. J., \& Fugate, B. (2019). Investigating green supply chain management practices and performance. International Journal of Operations \& Production Management. Vol. 39:5, pp. 767-786.

Devinney, T.M., (2009), Is the socially responsible corporation a myth? The good, the bad, and the ugly of corporate social responsibility, Academy of Management Perspectives 23 (2), 44-56.

Eisenhardt, K. M. (1989), "Building theories from case study research", Academy of Management Review, vol. 14, no. 4, pp. 532-550.

Eisenhardt, K. M., and M. E. Graebner (2007), "Theory building from cases, Opportunities and challenges", Academy of Management Journal, vol. 50, no. 1, pp. 25-42.

Ellram, L. M. (1996), "The use of the case study method in logistics research", Journal of Business Logistics, vol. 17, no. 2, pp. 93.

Fleischmann, M., Van Wassenhove, L.N., van Nunen, J.A.E.E., van der Laan, E.A., Dekker, R. and Bloemhof-Ruwaard, J.M. (1997), Quantita- tive models for reverse logistics: a review, European Journal of Operational Research, 103, 1-17.

Flynn, B. B., Sakakibara, S., Schroeder, R. G., Bates, K. A. and Flynn, E. J. (1990), "Empirical Research Methods in Operations Management", Journal of Operations Management, vol. 9, no. 2, pp. 250-284.

Garza-Reyes, J.A., Yu, M., Kumar, V. and Upadhyay, A. (2018), "Total quality environmental management: adoption status in the Chinese manufacturing sector", The TQM Journal, Vol. 30 No. 1, pp. 2-19.

George, A. L., and A. Bennett (2005), Case studies and theory development in the social sciences, The MIT Press.

Gomez-Trujillo, A.M., Velez-Ocampo, J. and Gonzalez-Perez, M.A. (2020), "A literature review on the causality between sustainability and corporate reputation: What goes first?", Management of Environmental Quality, Vol. 31 No. 2, pp. 406-430.

Green, K., Morton, B., and New, S. (1996), Purchasing and environmental management: interaction, policies and opportunities, Business Strategy and the Environment, Vol. 5, pp.188-197.

Guide, V.D.R., Spencer, M.S. and Srivastava, R. (1996), Are production systems ready for the green revolution? Production and Inventory Management Journal, Fourth Quarter, 70-78.

Guide, V.D.R. (2000), Production planning and control for remanufacturing: industry practice 
and research needs, Journal of Operations Management, 18, 467-483.

Gungor, A. and Gupta, S.M. (1999), Issues in environmentally conscious manufacturing and product recovery: a survey, Computers \& Industrial Engineering, 36, 811-853.

Hayes, R.H. and Wheelwright, S.C. (1984), Restoring our competitive edge; Competing through manufacturing, New York: Wiley.

Herriott, R. E. and Firestone, W. A. (1983), "Multi-site Qualitative Policy Research: Optimising Description and Unreliability", Educational Researcher, vol. 12, pp. 14-19.

Hervani AA, Helms MM, Sarkis J. (2005), Performance measurement for green supply chain management, Benchmarking: An International Journal, 12(4): 330-53.

Husted, B.W., (2003), Governance choices for corporate social responsibility: to contribute, collaborate or internalize? Long Range Planning, 36, 481-498.

Jaeger, B. and Upadhyay, A. (2020), "Understanding barriers to circular economy: cases from the manufacturing industry", Journal of Enterprise Information Management, Vol. 33 No. 4, pp. 1-17.

Jayaraman, V., Patterson, R.A. and Rolland, E. (2003), The design of reverse distribution networks: models and solution procedures, European Journal of Operational Research, 150, 128-149.

Klassen, R.D. and Johnson, P.F. (2004), The green supply chain. In Understanding Supply Chains: Concepts, Critiques and Futures, edited by S. New and R. Westbrook, Oxford University Press.

Kleindorfer, P.R., Singhal, K., van Wassenhove, L.N. (2005), Sustainable operations management, Production and Operations Management 14 (4), 482-492.

Krause, D.R., Scannell, T.V. and Calantone, R.J. (2000), A structural analysis of the effectiveness of buying firms' strategies to improve supplier performances, Decision Science, 31, 33-55.

Kumar, V., Holt, D., Ghobadian, A., \& Garza-Reyes, J. A. (2015). Developing green supply chain management taxonomy-based decision support system. International Journal of Production Research, 53(21), 6372-6389.

Kumar, N., Brint, A., Shi, E., Upadhyay, A., \& Ruan, X. (2019) Integrating sustainable supply chain practices with operational performance: an exploratory study of Chinese SMEs, Production Planning \& Control, Vol. 30:5-6, pp. 464-478.

Laing, T., Upadhyay, A., Mohan, M., \& Subramanian, N. (2019) Environmental improvement initiatives in the coal mining industry: maximisation of the triple bottom line, Production Planning \& Control, Vol. 30:5-6, pp. 426-436.Lee, S.Y. and Rhee, S.K (2007), The change in corporate environmental strategies: a longitudinal empirical study, Management Decision, 45 (2), pp. 196-216.

Linton, J.D., Klassen, R., and Jayaraman, V. (2007), Sustainable supply chains: An introduction, Journal of Operations Management, Vol. 25, 75-82.

Mangla, S., Madaan, J., \& Chan, F. (2013), "Analysis of flexible decision strategies for sustainability-focused green product recovery system", International Journal of Production Research. Vol. 51:11, pp. 3428-3442.

Mangla, S., Luthra, S., Rich, N., Kumar, D., Rana, N., and Dwivedi, Y. (2018), "Enablers to implement sustainable initiatives in agri-food supply chains", International Journal of 
Production Economics. Vol. 203, pp. 379-393.

Marshall, C. and Rossman, C. B. 1(999), Designing Qualitative Research, (3rd Edition), London: Sage.

Melnyk, S.A., Sroufe, R.P., and Calantone, R. (2003), Assessing the impact of environmental management systems on corporate and environmental performance, Journal of Operations Management, Vol. 21 (3), pp. 329-353.

Meredith, J. (1998), "Building operations management theory through case and field research", Journal of Operations Management, vol. 6, pp. 441-454.

Miles, M. B. and Huberman, M. A. (1994), Qualitative Data Analysis, Sage, Thousand Oaks, California.

Min, H., Galle, W.P. (1997), Green purchasing strategies: trends and implications, International Journal of Purchasing \& Materials Management, Vol. 33 No.3, pp.10-17.

Pennington, D.W., Potting, J., Finnveden, G., Lindeijer, E., Jolliet, O., Rydberg, T., Rebitzer, G. (2004), Life cycle assessment Part 2 Current impact assessment practice, Environment International, Vol. 30, 721-739.

Porter, M.E. (1980), Competitive Strategy, New York: The Free Press.

Prahalad, C.K. and Hamel, G. (1990), The core competence of the corporation, Harvard Business Review, Vol. 68, No. 3, pp. 79-91.

Rao, P., Holt, D. (2005), Do green supply chains lead to competitiveness and economic performance, International Journal of Operations \& Production Management, Vol. 25 No.9/10, pp.898-916.

Roberts, S. (2003), Supply chain specific? Understanding the patchy success of ethical sourcing initiatives, Journal of Business Ethics, Vol. 44 pp.159-70.

Srivastava, S. (2007), Green supply-chain management: A state-of-the-art literature review. International Journal of Management Reviews, Volume 9 Issue 1 pp. 53-80.

Stuart, I., McCutcheon, D., Handfield, R., McLachlin, R. and Samson, D. (2002), "Effective case research in operations management: a process perspective", Journal of Operations Management, vol. 20, no. 5, pp. 419-433.

Tseng, M. L., Islam, M. S., Karia, N., Fauzi, F. A., \& Afrin, S. (2019). A literature review on green supply chain management: Trends and future challenges. Resources, Conservation and Recycling, 141, 145-162.

Upadhyay, A., Akter, S., Adams, L., Kumar, V. and Varma, N. (2019), "Investigating "circular business models" in the manufacturing and service sectors", Journal of Manufacturing Technology Management, Vol. 30 No. 3, pp. 590-606.

Vachon, S. and Klassen, R.D. (2006), Extending green practices across the supply chain: the impact of upstream and downstream integration, International Journal of Operation and Production Management, 26, 795-821.

Vachon, S. (2007), Green supply chain practices and the selection of environmental technologies, International Journal of Production Research, 45:18-19, 57-79.

Van Aken, J. E. (2004), "Management Research Based on the Paradigm of the Design Sciences: The Quest for Field-Tested and Grounded Technological Rules", The Journal of Management Studies, vol. 41, no. 2, pp. 219.

Voss, C., Tsikriktsis, N. and Frohlich, M. (2002), "Case research in operations management", 
International Journal of Operations \& Production Management, vol. 22, no. 2, pp. 195219.

Walker H, Di Sisto L, McBain D. (2008), Drivers and barriers to environmental supply chain management practices: lessons from the public and private sectors, Journal of Purchasing and Supply Management, 14(1): 69-85.

Wu, Z. and Pagell, M. (2011), Balancing priorities: Decision-making in sustainable supply chain management, Journal of Operations Management, Vol. 29, pp.577-590.

Yin, R. K. (2003), Case study research, Design and Methods (3rd ed.), Sage Publications.

Zhang, H.C., Kuo, T.C., Lu, H. and Huang, S.H. (1997), Environmentally conscious design and manufacturing: a state-of-the-art survey, Journal of Manufacturing Systems, 16, 352-371.

Zhu, Q. and Sarkis, J. (2005), Relationships between operational practises and performance among early adopters of green supply chain management practices in Chinese manufacturing enterprises, Journal of Operations Management, 22, 265-289. 